\title{
Restructuring towards Sustainable Development: The Role Corporate Social Responsibility Should Play in the Development of the Niger Delta Region
}

\author{
Abraham Orhero \& Zephaniah Osuyi Edo \\ http://dx.doi./org/10.4314/ujah.v21i4.4
}

\begin{abstract}
The oil rich Niger Delta region is host to several big corporations that are involved in the exploration and extraction of her oil. Right from 1958 when oil was first exported in commercial quantity, the region has continued to play significant role in the budgetary calculation of Nigeria. However, despite its oil wealth, the Niger Delta is largely underdeveloped as its environment have been impacted negatively by the activities of oil multinationals and ignored by successive governments. Over the years, conflicts and oil theft have also affected its development. This is in spite of oil companies affirmed commitment to corporate social behavior. Corporate social responsibility (CSR) has been used to measure a company developmental commitment to host communities and it is a well settled argument that companies have a role to play no matter how minimal, either to mitigate the impacts of their activities or to enhance local participation. This paper attempts to look at how effective oil multinationals CSR is in the region, in the wake of increased spate of violence, social activism and massive environmental degradation.
\end{abstract}

Keywords: Corporate Social Responsibility, Environmental Responsibility, Niger Delta 


\section{Introduction}

Basically Nigeria is a mono product economy depending solely on oil production which is extracted from its Niger Delta region by licensed oil multinationals. The Niger Delta region is an oil rich region that is situated in the southern coast of Nigeria and it is the world largest wetland with a large forests zone of about 70,000 sq km. Its richness in oil is so vast that for over the past 40 years or so it has become the backbone of Nigeria economy accounting for over 90 percent of its national income (Ayorinde, 2007). Paradoxically it has also become conflict prone, pillaged by massive ecological disaster, neglect, high unemployment rate, social deprivation, poverty, decaying infrastructures and social amenities. It has also engendered civil strife and community conflicts. Studies have indeed linked such anomalies like community clashes and endemic poverty not only to the intensive extraction of oil with little regard to the environment but also to the "divide and share" policies of oil multinationals (see Jike, 2004; Evoh, 2002; ANEES, 2004).

Given the antagonistic relationship between host communities and oil companies and global trend towards Corporate Social Responsibility (CSR), it became imperative that for oil production to continue there must be conscious efforts by these oil companies to engage in socially acceptable behaviour. Therefore the corporate social responsibility engaged in by these companies is expected to help cushion or ameliorate the hardship endured by the inhabitants of these host communities primarily caused by oil exploitation and pollution. The relationship between any organization and the environment is not only intricate but it is should be one base on mutual interdependence. Any effort to disregard this axiom will surely be met with disdain. This is because why the organization depend on the environment for its inputs, the environment also depend on the organization for its sustenance. Thus, any studies on oil companies CSR in the Niger Delta must relate to how these companies avowed 
Orhero \& Edo: Restructuring towards Sustainable Development: The Role Corporate Social Responsibility Should Play in the Development of the Niger...

commitment to give back to host communities has helped to address the tension in the region. Also, such studies must look at the structural or systemic relationship between the host government and oil companies as this will give us greater insights and broader understanding into these companies brand of CSR.

\section{What is Corporate Social Responsibility}

The emergence of corporate social responsibility can be traced to the earlier twentieth century in the United States of America when big businesses were engaged in intense competitive drive. These big businesses were so powerful that their drive for profits led to serious anti-competitive practices and impacted negatively on the environment. According to Frederick (1992), it was the attempt by these corporations to cushion their anti competitive drive with voluntary social behavior towards society in general and the advancement of the social good that led to a situation where businesses became involved in charity works.

The concept received great impetus following the work of Bowen (1953) who posits that business firm's mission should not be exclusively economic but that the social implication of their decision should be taken into cognizance. This view was in sharp contrast to a more conservative view pursued by economist like Milton Friedman who in advancing the primacy of shareholders, sees them as 'principals' who hire directors as their agents to manage corporations and therefore the job of directors is to increase shareholders wealth through every means possible so long as the laws are not violated. Over the years, CSR have grown to great prominence that companies have to subscribe to it as it ensures the smooth running of their businesses.

CSR is a complex phenomenon and like many social sciences concepts lacks a universal definition. It is therefore not surprising that even among scholars there is hardly a consensus on the subject matter. 
One significant point that often leads to disagreement is what and what should be included in CSR provisions or programmes and how, if at all, can CSR be regulated. Despite this lack of agreement, there is little doubt that, CSR generally refers to the moral duty that a company own to the place where it conducts businesses. According to Ijaiya (2014:63), CSR is seen as the economic, legal, ethical, and discretionary expectations that society has of organizations at a given point in time. Ijaiya's definition is telling as he attempts to place society as the focal point. What this means is that society should not be seen as a dormant player but rather as an active participant. In the latter part of this paper, this point will be made clearer in our attempt to see why oil companies CSR has not yielded the much expected results.

Blowfield and Frynas (2005) considered CSR more as a bridge that links businesses to the discourse on development. Put differently, one of the more active ways businesses can positively contribute to the developmental effort of national governments is by their commitment to the practice of CSR. It is through CSR that the private sector can be active partners with any government in development goals. However since these big corporations are profit driven as we have seen from the Niger delta experience, is it possible to pursue profit while at the same time ensure the sustainability of the environment? According to Ojo (2012:12-13), "multinational oil companies CSR can subscribe to ethical codes for environmental stewardship within their operational systems and in ways that do not absolve them from their social responsibilities". If a business CSR does not contribute to a cleaner environment, as the Niger delta case shows, then there is the need for a rethink.

Globalization has played so great a role in the development of the practice of CSR. Wilenius (2005) alluded to this when he noted that while globalization has made global business very big and powerful since the 1990s, it has also led to the inter-connectedness 
Orhero \& Edo: Restructuring towards Sustainable Development: The Role Corporate Social Responsibility Should Play in the Development of the Niger...

and inter-dependency among governments, business organizations, society and individual. This has made multinational corporations (MNCs) to be more sensitive and responsible towards multiple stakeholders. Thus, under a globalized economy, it is no surprise that MNCs is seen as the "primary agent of change" (Collier and Wanderley, 2005).

Three international organizations worth noting that have contributed to the growing discourse of CSR are the Organizations for Economic Cooperation and Development (OECD), World Business Council for Sustainable Development (WBCSD), and Dow Jones Sustainability Group Indexes (DJSGI).

The WBCSD identified certain core values which they believe is integral to CSR. These values are:

- human rights

- employee rights

- environmental protection

- community development

- supplier relations

- monitoring and;

- stakeholder rights

It should be noted that these core values are directly related to how it defined CSR. The WBCSD defined CSR as the continuing commitment by businesses to behave ethically and contribute to economic development while improving the quality of life of the workforce and their families as well as the local community and society at large. This definition is consistent with the three fundamental pillars of sustainable development which are wealth creation, environmental improvement and social responsibility (Natufe, 2001).

The OECD while stressing the need for both companies and government to demonstrate their corporate responsibility by pursuing sound environmental and socially based policies did advice 
corporations among other things to contribute to economic, social and environmental progress with a view to achieving sustainable development; respect the human rights of those affected by their activities; and encourage local human capital formation through the creation of employment opportunities.

Lastly is the Dow Jones Sustainability Group Index. The DJSGI measure the performance of leading sustainability driven companies using such indices as technology, governance, shareholders, industry and society. The idea is that while companies' primary goal of profit making and satisfaction of stakeholders should not be threatened, society must not suffer during the quest to make money. Hence, companies must not only upgrade their technology and improved corporate governance but must also encourage lasting social well being.

A key element of CSR which is evident in all three conceptions is the protection and sustainable use of the environment and the application of environmental friendly technology. It is this drive that has given rise to the term "corporate environmental responsibility, a term which shows the rising importance of the environment not only in any CSR practice but even in security discourse. Ensuring environmental security is today at the heart of global protest in advanced economies.

\section{The Niger Delta and a Degraded Environment}

In spite of the Niger delta immense wealth, the region is considered as one of the poorest in the world (Watts, 2007). The traditional occupation of its inhabitants are fishing, farming and hunting. However, the extraction of oil has led to the destruction of farmlands and the contamination of waterways. Also the loss of biodiversity and the forced migration of certain animals like monkeys (Jike, 2004) due to unsustainable practices like gas flaring have affected so adversely the livelihood of host communities who depends largely on nature for 
Orhero \& Edo: Restructuring towards Sustainable Development: The Role Corporate Social Responsibility Should Play in the Development of the Niger...

survival. The unemployment rate in the region is one of the highest in the world. This is not surprising as the very source of income in the region has been degraded. More so, the oil industry which is more of a technical and specialized industry is unable to employ because many lack the technical expertise to work there.

According to Jike (2004), the major cause of "environmental degradation in the Niger delta is petroleum exploration. Jike went on to say that "ancillary problems of spillage and other causes of environmental degradation pale into insignificance when pitched against the backdrop of oil exploration and the unintended consequences of spillage that have largely become the cog in the wheel of development in the Niger delta". For example, it has been estimated that an average of 240,000 barrels of crude oil are spilled every year mainly due to mechanical or equipment failures, unknown sources, and third party activities (Cordinwa and Brisibe, 2013). The consequence is that these spills contaminate surface water, ground water, and crops with hydrocarbons which have adverse effects on human health. Very recently, a study carried out in the University of St. Gallen in Switzerland which draws a link between environmental pollution with newborn and child mortality rates in the Niger delta "shows that oil spills occurring within $10 \mathrm{~km}$ of a mother's place of residence doubled neon-natal mortality rates and impaired the health of her surviving children" (Hodel, 2017).

While oil companies like Shell is quick to blame oil spills on sabotage, there are serious doubts as to Shell reports of oil spills in the region. For instance, in 2008, Shell reported an oil spill from a faulty weld pipelines to be in the region of 1640 barrels which was spill into the creeks near the town of Bodo in Ogoniland. However, an independent US oil spills consultancy film Accufacts, believed that a total of between 103, 000 barrels and 311,000 barrels of oil flooded into the Bodo creeks over the period of the leak, (Vidal, 2012).

Ojo (2012), stated that the average yearly oil spills in the 
Niger delta account for about twice that of BP Gulf of Mexico deep water horizon oil blowouts in 2010. Placed in perspective, one begins to see what the inhabitants of the region suffer from, given the global outcry that greeted the BP gulf of Mexico oil spillage.

Gas flaring is another oil related activity that has negatively impacted on the environment of the region. Since the discovery of oil, gas flaring has continued unabated. Oil companies have continued to flare associated gas into the air as it is considered cheaper to flare gas than to re-inject it for domestic uses. It is estimated that Nigeria accounts for about $40 \%$ of gas flared annually in Africa (Umoru, 2017). While there have been tremendous effort made in reducing the flaring of gas in the Niger delta, according to the World Bank, Nigeria still remains the $7^{\text {th }}$ largest flarer of gas in the world (World Bank, 2016). Due to the effect of gas flaring on crops, health and biodiversity, the federal government has enacted policies aim at stopping gas flaring in the region. By section 2 of the Re-injected Gas Flaring Act of 1979, the federal government banned the flaring of gas effective from January 1, 1984 with penalty or sanctions. However, the deadline was not met for various reasons. Aside the penalty which was considered as too severe by stakeholders and the fact that oil companies claims that the infrastructure needed to stop gas flaring was beyond their reach at the time e.g., infrastructures for gas utilization like gas pipelines, storage tanks, and gas re- injection plants, the federal government failure to contribute its share of the cost in building re injection facilities was a major factor for the policy failure, (Nelson, 2015). Subsequently, the fine was reduced in 1984 which makes it cheaper to flare gas.

The Associated Gas Re-injection (Continued Flaring of Gas) Regulations (AGRA Regulation) were promulgated in January 1985 to extend the period of flaring. Although the fine for flaring has been reviewed and increased severally between 1990 and 1998, the amount remains pointedly low compared to the cost of re-injection. Efforts to 
Orhero \& Edo: Restructuring towards Sustainable Development: The Role Corporate Social Responsibility Should Play in the Development of the Niger...

stop gas flaring by successive democratic administration in Nigeria have failed due to lack of political will on the part of its leadership (Malumfashi, 2007). Till date, gas flaring continues to be flared affecting the livelihood and health of communities.

The grievances of host communities against these unsustainable practices have led to serious agitations and protests that have taken several forms. According to Jike (2004), these forms include the migration of the youths in search of greener pasture far away in urban metropolitan centers, outright rebelliousness, the creation of parallel organizational structures, and the total disregard for traditional authority. Pipelines vandalism and kidnapping have also been employed by the grieving youths of the region. All of these have made the Niger delta an unsafe place to stay or do business. The culpability of the government has made things worse as the government have been seen as partners to the oil companies rather than regulator. In fact there is a growing body of literature that continues to linked the failure of governance to the conflicts that have engulfed the region. The argument is that there has been a deliberate attempt by the government to undermine community grievances through wasteful and corrupt management of the Niger delta resources, and the militarization of the region (Seun, 2008; Ibaba, 2008). The idea of CSR by the oil companies must be understood under such hostility.

\section{The Implementation of CSR in the Niger Delta}

The advent of corporate social responsibly in the Niger delta region can be traced back to the Ogoni crisis of the 1990s which was triggered by serious allegations being leveled against the oil companies and the Nigerian government. These allegations of human rights abuses and massive ecological disaster carried out by Movement for the Survival of the Ogoni People and led by the playwright Ken Saro Wiwa drew global condemnation of oil 
companies' unsustainable practices in the region. In the bid to regain an already damaged image, Shell, the company directly involved in the Ogoni conflicts and other oil companies committed to CSR.

Over the years, these companies have been heavily involved in undertaking various community developments projects such as the building of health centers, primary and secondary school blocks, provision of water, scholarships, and so on aimed at addressing the problems of underdevelopment of the region (Emeseh, 2009). for instance, according to Lugard (2014), Shell has made significant stride in the area of agriculture, education, training, health care, capacity building and overseas sponsorship of research programs in Geo-sciences in about some universities in the region. Between 2011 and 2012, Shell spent over 200 million dollars in pursuant of its CSR commitment. Shell has contributed to community development, aided the Niger Delta Development Board (NDDC) in the implementation of projects which includes electrification projects, water projects, canalization projects, jetties and bridges (This Day, 2006)

Other oil companies have followed suit. Exxon Mobile and Elf Petroleum are good examples. Ukwaji, Eja, and Ojong (2012) in their study of Exxon noted that the company has made appreciable contribution in airports development, building of class room blocks, hospitals, seaports, roads and electrification. However, while all of these are important aspects of CSR aimed at addressing certain peculiar problems of the region, its practices in the Niger Delta is unsustainable as "projects are selected adhoc, communities have no real inputs, long term visibility of projects are not built into plans and thus no real impact is seen" (Emeseh, 2009). Another area where the CSR of these companies have been questioned is in the area of local participation and decision making. Oil companies, aside engaging in a kind of divide and share policy drive which aim to target those they felt are direct threat to their operations have failed to involve those directly suffering from their activities to have direct role in decisions 
Orhero \& Edo: Restructuring towards Sustainable Development: The Role Corporate Social Responsibility Should Play in the Development of the Niger...

and choice and implementation. According to Emeseh (2009), this is in sharp contrast to what is seen in other climes like Canada where public participation in the decision of mining development is central and Rio Tinto community projects amongst aborigines of Australia.

Another example is the Environmental Impact Assessment (EIA) which is aimed at encouraging local participation. Despite the fact that the EIA afford oil companies the opportunity to actively involve host communities in the location of projects and collectively discussed on measures to be taken to mitigate impacts such as the destruction of traditional occupations and erosion of traditional cultures and institutions, the fact is that the EIA is hardly adhere to. Jike (2004) noted that "the quality, size and shape of traditional staples such as cassava, yam, plantain, and so on, are adversely affected by the continuing forage for oil without the requisite environmental impact assessment". All of these explains why despite serious commitment given to the development of Basic infrastructure and provision of social amenities and services, the people of the Niger Delta still felt marginalized by the oil companies and the government.

\section{CSR in the Niger Delta and the Need for Restructuring}

Oil exploration in the Niger delta has had adverse effects on fish production, farming activates, and hunting. Ideally therefore, it is expected that oil companies CSR should target the environment as this is the primary source of grievances among the region's inhabitants and the core of community's agitation and international condemnation. While it is true that millions of dollars have been spent on philanthropic gestures, the lack of sustainability in the CSR approach is what that has been the basis of conflicts.

One of the key elements of corporate social responsibility inherent in its conception is the notion of environmental responsibility. Mazurkiewicz (2005) posit that "environmental responsibility is the duty for companies to cover the cost of 
implications of the company operations, products and facilities, eliminate waste and emissions, maximized the efficiency and productivity of its resources and minimize practices that might adversely affects the enjoyment of the country's resources by future generation". Environmental responsibility according to this definition is linked to sustainable development and that is why Jike (2004) believes that the environment must be the starting point for any meaningful solution to the Niger Delta crisis.

It is evidently clear that this does not factor much in oil multinationals brand of CSR at the moment as the sights of gas flaring in host communities and the continuing spillage of oil in the environment shows. While the various big players in the oil industry have shown certain commitment towards addressing the development deficit in the region, the reality on ground is not supportive of these commitments. For example, Shell while admitting the use of outdated facilities and equipments, promised a replacement and a desire to bring its operation in line with Nigeria regulations by 1999. There have also been commitments in other areas like improvements of EIA process on all new projects in accordance with international standards, gas flaring reduction, increased preparedness to respond to oil spills, and increased remedial actions to rehabilitate environmentally devastated areas (Emeseh, 2009). The inability of Shell and other oil multinationals to fulfill their promises has further seen the end date for gas flaring extended to 2030 by the National Assembly.

Other companies like Chevron and ELF Petroleum have shown similar commitment to end gas flaring, and reduce to zero incidences, oil spillage. But the fact that these disasters are still a common feature in the region have called to questions this commitments. This paper is therefore advancing the view that oil companies adherence to sound environmental standards will go a long way in addressing grievances in the region. 
Orhero \& Edo: Restructuring towards Sustainable Development: The Role Corporate Social Responsibility Should Play in the Development of the Niger...

Another pragmatic step oil companies can take is that their CSR must be peopled-oriented. Ojo (2012) has noted the lack of transparency and non-involvement of local people in the monitoring of oil companies activities. Hence, there is what he called a dialogue deficit in the CSR operations of oil companies and engagement of host communities. A more proactive CSR will involve the people who are suppose to be the primary recipient in the design, planning and implementation of any projects by oil multinationals. But this is sadly not the case. Ojo (2012), therefore called for a timely transition from the lowly stage of philanthropy to the more desirable social responsibility guided by obligatory legal mechanisms. One of the advantages of such a transition is that it will help to de- emphasize a compensation syndrome that is more of a trap and one that turns attention away from environmental responsibility or the real issues of ecological devastation in the region. There is therefore the need to incorporate or mainstream the practice of CSR into existing environmental legislation in Nigeria is imperative. This will place obligations on oil companies to address serious environmental degradation in the region.

\section{Conclusion}

The goal of corporate social responsibility should be aimed at affecting people's lives in ways that ensures sustainable development. The quest for sustainable development is anchored on the belief that future generation quest for the 'good life' must not be destroyed by our unsustainable actions or activities today. The desire for profit by companies as understandable as it is, should not be at a devastating cost to the environment. As Ojo (2012), quoting Idemudia (2008) puts it "business's affirmative duties" is to "contribute to development and...... to avoid contributing to underdevelopment or correcting development problems arising from its operations". This will imply that oil multinationals should have no excuse for not using sound 
environmental technology in their operations. If the CSR of oil companies must meet the concept of sustainable development, Oil companies' commitment to corporate social responsibility must include therefore a commitment towards environmental responsibility as this is the very source of grievances in host communities.

\section{Abraham Orhero (PhD) \& Zephaniah Osuyi Edo \\ Department of Political Science \\ Delta State University, Abraka}

\section{References}

Amuyon, U. A. et al (2016). "International oil companies corporate social responsibility - failure as a factor of conflicts in the Niger delta area of Nigeria". Journal of research in humanities and social sciences, 4(11), pp. 65-72

ANEES. (2004). "Oil of poverty in Niger Delta", http://www.nigerdeltaing/framesp/pdf. Retrieved on Nov 8 2007

Ayorinde, B. (2007). "The Challenges of Corporate Social Irresponsibility in the Niger Delta Region of Nigeria: The imperative of Legislative Reform-----

Blowfield, M. and Frynas, J. G. (2005). "Setting New Agendas Critical Perspectives on Corporate Social Responsibility in the Developing World". International Affairs, 81(3); pp 499-513

Bowen H.R. (1953). Social Responsibility of the Businessman. Harper; New York.

Chatterji, A. K. and Richman, B. D. (2008). "Understanding the "Corporate" in Corporate Social Responsibility". Harvard Law \& Policy Review, Vol 2.

Collier, J., \& Wanderley., L. (2005). "Thinking for the future: global corporate responsibility in the twenty-first century", Futures, 
Orhero \& Edo: Restructuring towards Sustainable Development: The Role Corporate Social Responsibility Should Play in the Development of the Niger...

37, $169-182$

Emeseh, E. (2009). "Social responsibility in practice in the oil producing Niger delta: Assessing corporations and government actions". Journal of Sustainable Development in Africa, 11(2); pp. 113-125

Evoh, C. (2002), "Gas Flares, Oil Companies and Politics in Nigeria. The Guardian on line - http://ngrguardiannews.com. Retrieved on February 82008.

Malumfashi, G. I. (2007). "Phase-Out of Gas Flaring in Nigeria By 2008: The Prospects of a Multi-Win Project (Review of the Regulatory, Environmental and Socioeconomic Issues)' Nigeria Gas Flaring Petroleum Training Journal, Vol. 4, No. 2, p. 1269

Global Gas Flaring Reduction Partnership Gas Flaring Definitions June 29, 2016 available at http://pubdocs.worldbank.org/en/876011467068652330/GGF R-Gas-Flaring-Definitions-29-June-2016.pdf accessed 26, August 2019

Hodel, K. (2017). "Absolutely Shocking: Niger Delta Oil Spills Linked With Infant Death" The Guardian, Nov 6.

Idemudia, U. (2008). "Conceptualising the CSR Development Debate, Bridging Existing Analytical Gaps". Journal of Corporate Citizenship, 28, 91-110.

Ijanya, H. (2014). "Challenges of Corporate Social Responsibility in the Niger Delta Region of Nigeria". Journal of Sustainable Development, Law and Policy, 3(1); Afe Babalola University

Jike, V. T. (2004). "Environmental Degradation, Social Disequilibrium, and the Dilemma of Sustainable Development in the Niger Delta of Nigeria". Journal of Black Studies, 34(5); 686-701

Mazurkiewicz, P. (2005). "Corporate Environmental Responsibility: Is a Common CSR Framework Possible?" A Discussion 
Paper, DevComm, World Bank

Natufe, O. I. (2001). "The Problematic of Sustainable Development and Corporate Social Responsibility: Policy implication for the Niger Delta". Being a Paper Presented on the Second Annual Conference and General meeting of the Rockaway River Country Club Denville, New Jersey, U.S.A.

Nelson, N. (2015) 'National Energy Policy and Gas Flaring in Nigeria' JE\&ES, 5 (1)

Ojo, U. O. (2012). "Community Perception and o=Oil Companies Corporate Social Responsibility Initiative in the Niger Delta. Studies in sociology of science. 3(4); pp 11-21

Ordinioha, B. and Brisibs, S. (2013). "The Human Health Implications of Crude Oil Spills in the Niger Delta, Nigeria: An Interpretation of Published Studies", Niger Med. J., 54(1), $10-16$

Umoru, H.(2017). "Nigeria Accounts for 40 Percent of Gas Flared Annually in Africa - Senate" Vanguard Newspaper, Lagos, 1 June

Vogel, D. (2005). The Market for Virtue: The Potential and Limits of Corporate Social Responsibility. Washington DC: Brooking Institution Press

Watts, M. (2007). "Petro-Insurgency or Criminal Syndicate? Conflict and Violence in the Niger Delta". Review of African Political Economy, 34(4), 637-660.

Wilenius, M. (2005). "Towards the age of corporate responsibility, Emerging challenges of the business world", Futures, (37), 133-150. 48 